\title{
PERMINTAAN, PENAWARAN DAN KESEIMBANGAN HARGA DALAM PRESPEKTIF EKONOMI MIKRO ISLAM
}

\author{
M. Dliyaul Muflihin \\ STIES Kanjeng Sepuh Gresik \\ e-mail: mdliyaulmuflihin@gmail.com
}

\begin{abstract}
In general, we believe that humans are social creatures with the need to complement each other's lives, with each other's unlimited desires. While a Muslim is only allowed to consume halal and good. In Islamic teachings, illicit goods for consumption are not allowed to be made the basis of buying and selling or other transactions. In the demand and supply curves of Islam there are restrictions that must be done as a Muslim which is used as a basis for economic behavior. These restrictions are prohibited from making mafsadah, gharat, maisir, usury. This paper will answer the question how is the demand, supply and price balance in the perspective of Islamic microeconomics. The results of research shows that the concept of demand and supply in Islamic Islam aims to obtain prosperity or victory in the hereafter (falah) as a derivation of the belief that there is an eternal life after death, namely the after life, so that the existing budget must be set aside as provisions for the afterlife, such as alms and zakat. This means that there is a significant difference between conventional demand theory and Islamic demand theory. In conventional economics, consumers and producers have motivations that are dominated by the values of satisfaction, but in Islamic economics emphasizes only the level of need. The Islamic price balance mechanism in Islam is determined by the balance between demand and supply. This means that the price balance in the market is formed naturally, not because there is interference from the capitalist who can distort the market. This shows that the price regulation is left to the natural impersonal market mechanism.
\end{abstract}

Keywords: Demand, Supply, Islamic perspective

\section{Pendahuluan}

Pada umumnya kita mempercayai bahwa manusia merupakan makhluk sosial yang berkebutuhan untuk saling melengkapi hidup satu sama lain dengan keinginan masing-masing yang tidak terbatas. Sementara seorang muslim hanya diperbolehkan mengkonsumsi yang halal dan tayyib.

$$
\text { يا أيها الناس كلوا مما في الأرض حلالا طيبا ولا تتبعوا خطوات الشيطان إنه لكم عدو مبين1 }
$$

"Wahai manusia, makanlah apa-apa yang halal dan baik yang ada di bumi dan janganlah kalian mengikuti langkah-langkah setan. Sesungguhnya setan bagimu adalah musuh yang nyata."

\footnotetext{
${ }^{1}$ al-Quran, 2: 168.
} 
Dalam ajaran Islam, barang yang haram untuk dikonsumsi tidak diperkenankan untuk dijadikan dasar transaksi jual beli maupun yang lain. Adanya permintaan dan penawaran akan barang dan jasa sebenarnya sudah dijelaskan dalam al-Quran:

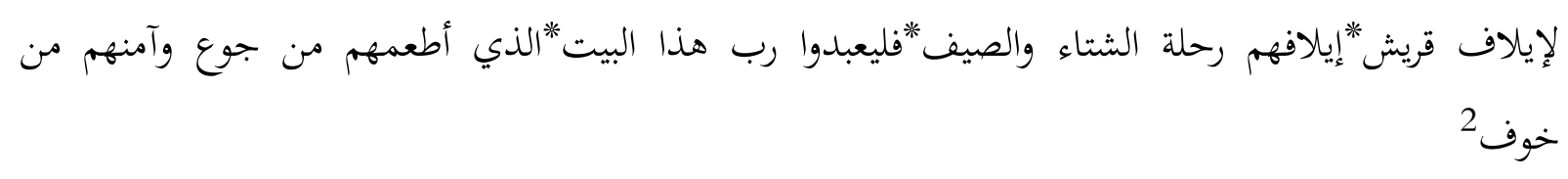

"Karena kebiasaan orang-orang Quraish, yaitu kebiasaan mereka bepergian pada musim dingin dan musim panas, ${ }^{3}$ maka hendaklah mereka menyembah Tuhan rumah ini (Ka'bah) yang telah memberi makanan kepada mereka untuk menghilangkan lapar dan mengamankan mereka dari ketakutan."

Dalam ayat tersebut dijelaskan bahwa orang-orang Quraish biasa mengadakan perjalanan terutama untuk berdagang ke negeri Syam pada musim panas dan ke negeri Yaman pada musim dingin. Ini menunjukkan adanya transaksi ekonomi dikarenakan adanya permintan dan penawaran yang disebabkan oleh perbedaan musim, sehingga terjadilah transaksi dan kesepakatan harga.

Ekonomi mikro konvensional mempelajari bagaimana perilaku-perilaku individu tersebut dalam memenuhi kebutuhan maupun keinginannya yang didasarkan pada perilaku individu-individu yang secara nyata terjadi pada setiap unit ekonomi, di mana perilaku para pembeli dan penjual tersebut secara alamiah akan mendorong terciptanya harga dalam mekanisme pasar ke arah keseimbangan. Apabila harga pasar berada di atas harga keseimbangan maka akan terjadi kelebihan penawaran yang kemudian akan medorong harga pasar menurun, namun apabila harga pasar berada di bawah harga keseimbangan maka terjadilah kelebihan permintaan yang menyebabkan harga meningkat.

Adapun teori harga merupakan alat utama teori ekonomi mikro. Teori harga digunakan untuk menganalisa komposisi dan alokasi produk dan sumber-sumber atau input. Barang mempunyai harga disebabkan dua alasan, yaitu pertama, barang dibutuhkan manusia, dan kedua, ketersediaan barang terbatas atau langka. Karena itu, harga barang ditentukan oleh permintaan dan penawaran. ${ }^{4}$

Perubahan harga akan mempengaruhi jumlah barang yang diminta dan jumlah barang yang ditawarkan. Perubahan itu diukur melalui elastisitas. Macam elastisitas di antaranya elastisitas permintaan, elastisitas penawaran, elastisitas silang, elastisitas pendapatan, dan elastisitas produksi. Untuk melindungi konsumen dan produsen, pemerintah menetapkan kebijakan harga melalui pembatasan produksi, harga dasar atau harga minimum, subsidi, dan

\footnotetext{
2 Ibid., 106: 1-4.

${ }^{3}$ Orang Quraish biasa mengadakan perjalanan terutama untuk berdagang ke negeri Syam pada musim panas dan ke negeri Yaman pada musim dingin. dalam perjalanan itu mereka mendapat jaminan keamanan dari penguasapenguasa dari negeri-negeri yang dilaluinya. Ini adalah suatu nikmat yang amat besar. Oleh karena itu, sepatutnya mereka menyembah Allah yang telah memberikan nikmat itu kepada mereka.

4 Abdul Hafidh, "Konsep Penawaran Dalam Perspektif Islam”, JEBIS, Vol. 1, No. 2 (Juli - Desember 2015), 203.
} 
harga maksimum. Dampak kebijakan harga tersebut tergantung pada elastisitas. ${ }^{5}$

Sebagaimana yang telah dikemukakan oleh para ahli, ekonomi Islam hadir menjawab persoalan-persoalan perilaku individu yang dalam ilmu ekonomi konvensional hanya berkutat pada persoalan pemenuhan kebutuhan yang tidak jarang lebih mengedepankan pada kepuasan masing-masing, dengan lebih mempertimbangkan faktor norma serta moral yang terangkum dalam tatanan syariah yang bersumber pada al-Quran, hadis serta ijmä, dan qiyass.

Dasar dari pengembangan ilmu ekonomi mikro tidak akan terlepas pada permasalahan penentuan tingkat harga yang diderivasikan dari proses mekanisme pasar. Sedangkan mekanisme pasar sendiri terbentuk karena adanya perpaduan antara teori permintaan dan teori penawaran yang dapat berjalan dengan baik. Sehingga kita pun harus mengakui bahwa analisis ekonomi manapun tidak akan terlepas dari kedua dasar tersebut. Artinya, teori permintaan dan teori penawaran adalah dasar pembentukan ilmu ekonomi yang sangat luas. ${ }^{6}$

Dengan demikian, konsep keseimbangan, penawaran dan keseimbangan pasar juga perlu untuk dikaji dalam perspektif Islam. Tulisan ini akan menjawab pertanyaan tentang konsep permintaan dan penawaran dalam Islam, dan konsep keseimbangan harga pasar dalam Islam.

\section{Konsep Permintaan dan Penawaran dalam Islam}

Permintaan adalah banyaknya barang yang diminta pada suatu pasar tertentu dengan tingkat harga tertentu pada tingkat pendapatan tertentu dan dalam periode tertentu. ${ }^{7}$ Teori permintaan menerangkan tentang ciri hubungan antara jumlah permintaan dan harga. Permintaan seseorang atau suatu masyarakat kepada suatu barang ditentukan beberapa faktor. Di antara faktor-faktor tersebut yang terpenting adalah ${ }^{8}$ harga barang itu sendiri; harga barang lain yang berkaitan erat dengan barang tersebut; pendapatan rumah tangga dan pendapatan rata-rata masyarakat; cita rasa masyarakat; jumlah penduduk; dan ramalan mengenai keadaan di masa yang akan datang.

Dalam analisis ekonomi dianggap bahwa permintaan suatu barang terutama dipengaruhi oleh tingkat harganya. Dalam analisis tersebut diasumsikan bahwa faktor-faktor lain tidak mengalami perubahan atau cateris paribus. ${ }^{9}$

Dalam hukum permintaan dijelaskan sifat hubungan antara permintaan suatu barang dengan tingkat harganya. Hukum permintaan pada hakikatnya merupakan suatu hipotesis yang menyatakan bahwa makin rendah harga suatu barang maka makin banyak permintaan terhadap barang tersebut. Sebaliknya, makin tinggi harga suatu barang maka makin sedikit permintaan terhadap barang tersebut. ${ }^{10}$

\footnotetext{
${ }^{5}$ Ibid., 204.

${ }^{6}$ Adiwarman A. Karim, Ekonomi Mikro Islam (Jakarta: Rajawali Press, 2012), 13.

${ }^{7}$ Muhammad, Ekonomi Mikro dalam Perspektif Islam (Jogjakarta: BPFE, 2004), 113.

${ }^{8}$ Sadono Sukirno, Mikro Ekonomi: Teori Pengantar (Jakarta: PT. Raja Grafindo Persada, 2010), 76.

${ }^{9}$ Ibid.

${ }^{10} \mathrm{Ibid}$
} 


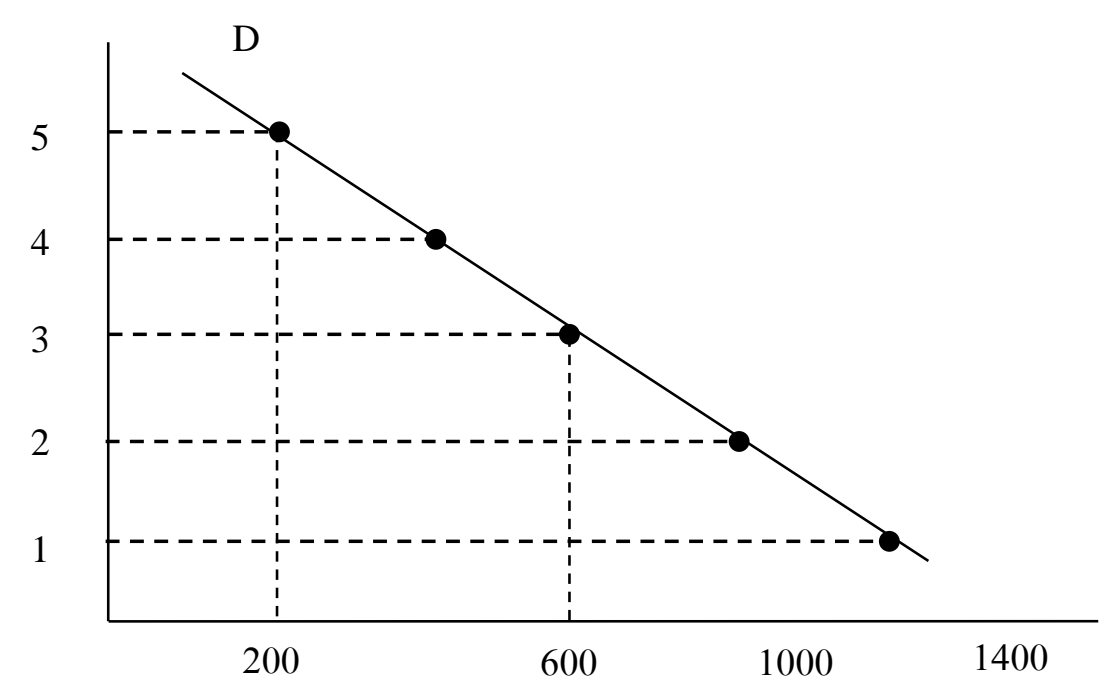

Slope yang menurun disebabkan perilaku rasional dari konsumen, yaitu apabila harga naik mereka akan menurunkan konsumsinya, sebaliknya bila harga turun mereka akan menaikkan konsumsinya. Di mana satu-satunya faktor hanya dipengaruhi oleh perubahan tingkat harga. Hal inilah yang dalam ilmu ekonomi disebut pergerakan sepanjang kurva (moving along the curve), di mana perubahan konsumsi hanya terjadi di sepanjang kurva permintaan tersebut dan tidak terjadi pergeseran dalam kurva permintaan. ${ }^{11}$

\section{Teori Permintaan Islami}

Perbedaan utama antara kedua teori tersebut tentunya adalah mengenai sumber hukum dan adanya batasan syariah dalam teori permintaan islami. Permintaan Islam berprinsip pada entitas utama, yaitu Islam sebagai pedoman hidup yang langsung dari oleh Allah.

Sementara itu, dalam ekonomi konvensional filosofi dasarnya terfokus pada tujuan keuntungan dan materialisme. Hal ini wajar saja karena sumber inspirasi ekonomi konvensional adalah akal manusia yang tergambar pada daya kreatifitas, daya olah informasi dan imajinasi manusia. Padahal akal manusia merupakan ciptaan Tuhan yang memiliki keterbatasan.

Konsep permintaan dalam Islam menilai suatu komoditi tidak semuanya bisa untuk dikonsumsi maupun digunakan, dibedakan antara yang halal maupun yang haram. Allah telah berfirman:

$$
\text { وكلوا مما رزقكم الله حلالا طيبا واتقوا الله الذي أنتم به مؤمنون } 12
$$

"Dan makanlah makanan yang halal lagi baik dari apa yang Allah telah rezekikan kepadamu, dan bertakwalah kepada Allah yang kamu beriman kepada-Nya."

Oleh karenanya, dalam teori permintaan Islam membahas permintaan barang halal, barang haram, dan hubungan antara keduanya. Sedangkan dalam permintaan konvensional, semua komoditi dinilai sama, bisa dikonsumsi atau digunakan.

\footnotetext{
${ }^{11}$ Nur Rianto Al Arif dan Euis Amalia, Teori Mikroekonomi: Suatu Perbandingan Ekonomi Islam dan Ekonomi Konvensional, (Jakarta: Kencana, 2010), 47.

${ }^{12}$ al-Quran, 5: 88.
} 
Dalam motif permintaan Islam menekankan pada tingkat kebutuhan konsumen terhadap barang tersebut sedangkan motif permintaan konvensional lebih didominasi oleh nilai-nilai kepuasan (interest). Konvensional menilai bahwa egoisme merupakan nilai yang konsisten dalam mempengaruhi seluruh aktivitas manusia.

Permintaan Islam bertujuan mendapatkan kesejahteraan atau kemenangan akhirat (falah) sebagai turunan dari keyakinan bahwa ada kehidupan yang abadi setelah kematian, yaitu kehidupan akhirat sehingga anggaran yang ada harus disisihkan sebagai bekal untuk kehidupan akhirat, seperti sedekah dan zakat. ${ }^{13}$

\section{Pergeseran Kurva Permintaan}

Selain perubahan harga, tentu ada faktor-faktor lain yang dapat menyebabkan perubahan kurva permintaan. Faktor-faktor selain harga yang mengubah kurva permintaan dalam ilmu ekonomi dikenal sebagai pergeseran kurva permintaan (shifting the demand curve), di mana kurva permintaan akan bergeser apabila terjadi perubahan selain harga. Kurva permintaan dapat bergeser ke arah kanan maupun kiri tergantung perubahan yang terjadi. ${ }^{14}$

Diumpamakan bahwa pendapatan para pembeli mengalami kenaikan. Apabila faktorfaktor lain tidak mengalami perubahan, kenaikan pendapatan ini akan menaikkan permintaan, yaitu pada setiap tingkat harga jumlah yang diminta menjadi bertambah banyak. ${ }^{15}$

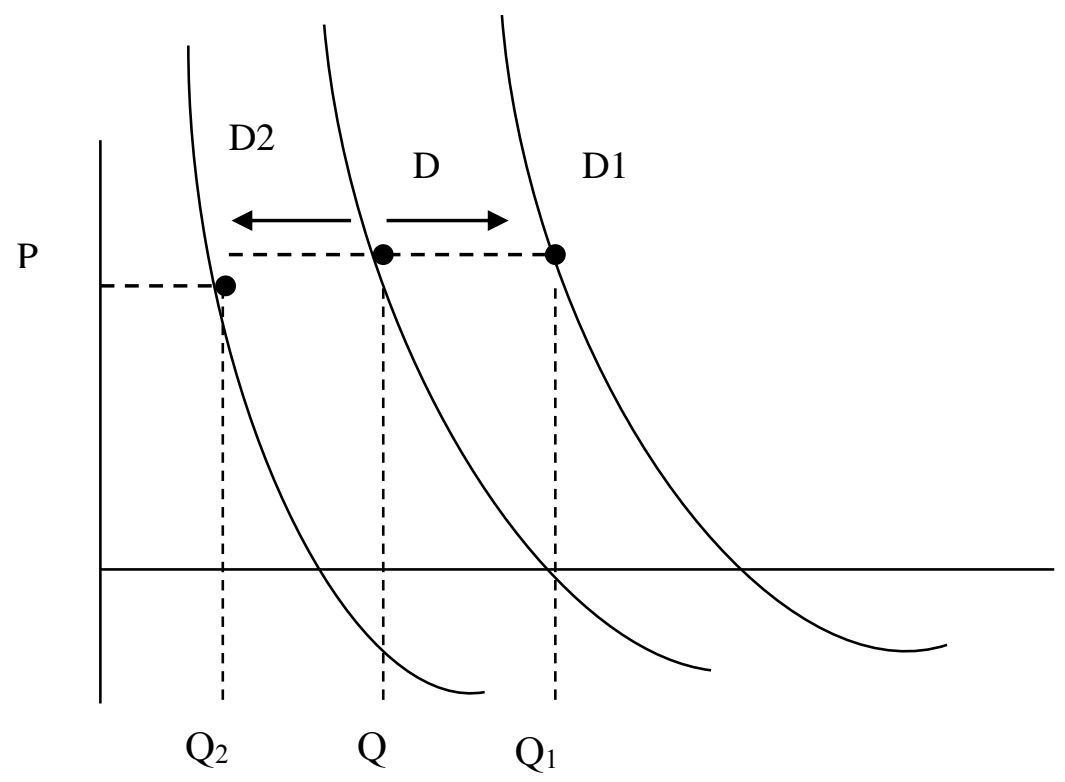

\section{Pengertian, Hukum dan Teori Penawaran}

Penawaran adalah banyaknya barang yang ditawarkan oleh penjual pada suatu pasar tertentu, periode tertentu dan pada tingkat harga tertentu. ${ }^{16}$ Hubungan antara jumlah barang yang ditawarkan dengan harga barang adalah hubungan searah. Jika harga barang tinggi maka akan lebih banyak orang yang melihat potensi mendapatkan keuntungan dengan menjual

\footnotetext{
${ }^{13}$ Ismail Nawawi, Ekonomi Mikro dalam Perspektif Islam (Jakarta: CV. Dwiputra Pustaka Jaya, 2010), 23.

${ }^{14}$ Nur Rianto Al Arif dan Euis Amalia, Teori Mikroekonomi, 48.

${ }^{15}$ Sadono Sukirno, Mikro Ekonomi: Teori Pengantar, 84.

${ }^{16}$ Muhammad, Ekonomi Mikro, 139.
} 
barang yang diproduksi atau dimilikinya, sehingga jumlah penawaran barang tersebut pun akan tinggi. Sebaliknya, apabila harga turun maka jumlah penawaran pun akan turun. Lebih sedikit orang yang dapat memperoleh keuntungan dari harga yang rendah, sedangkan mereka yang tidak memperoleh keuntungan dari harga rendah akan menunda penjualan, akibatnya jumlah penawaran di pasar pun akan berkurang. ${ }^{17}$

Hubungan antara jumlah penawaran barang dan jasa dengan harga barang atau jasa itu sendiri dinyatakan dalam hukum penawaran, ${ }^{18}$ yaitu perbandingan lurus antara harga terhadap jumlah barang yang ditawarkan, yaitu apabila harga naik maka penawaran akan meningkat, sebaliknya apabila harga turun maka penawaran akan turun.

Hukum tersebut menunjukkan adanya hubungan penawaran dengan harga. Teori penawaran mengatakan bahwa jika jumlah barang yang ditawarkan sangat banyak, maka harga barang tersebut cenderung turun. Sebaliknya, bila jumlah penawaran barang tersebut relatif sedikit, maka harga barang akan cenderung naik. Teori ini dapat dijelaskan, jika pada suatu pasar terdapat penawaran suatu produk yang relatif sangat banyak, maka ${ }^{19}$ pertama, barang yang tersedia di pasar dapat memenuhi semua permintaan, sehingga untuk mempercepat penjualan produsen akan menurunkan harga jual produk tersebut. Kedua, penjual akan berusaha untuk meningkatkan dan memperbesar keuntungan dengan cara secepat mungkin dengan memperbanyak jumlah penjualan produknya.

Sebaliknya jika suatu pasar terjadi penawaran suatu produk relative sedikit, maka yang terjadi adalah harga akan naik. ${ }^{20}$ Pertama, barang yang tersedia pada produsen relatif sedikit sehingga manakala jumlah permintaan stabil, maka produsen akan berusaha menjual produknya dengan menaikkan harga jualnya. Kedua, produsen atau penjual hanya akan meningkatkan keuntungannya dari menaikkan harga.

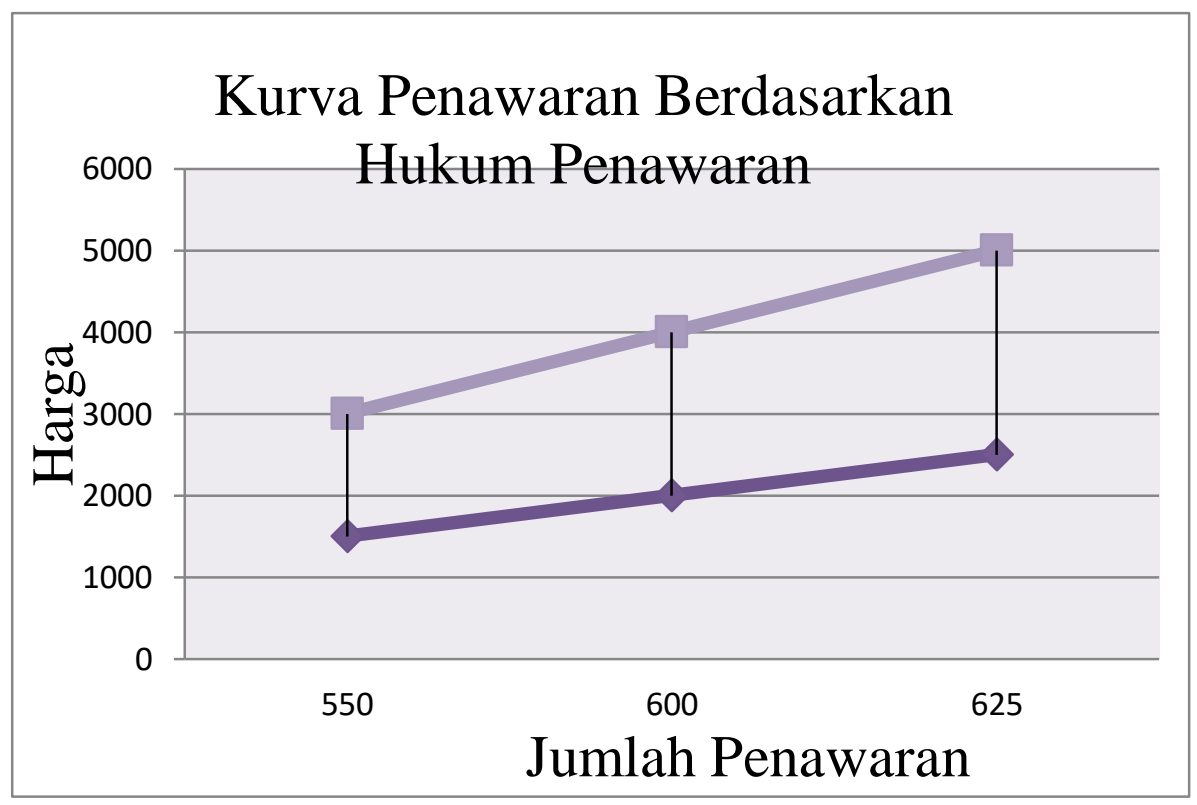

\footnotetext{
${ }^{17}$ Mustofa Edwin Nasution, Ekonomi Islam: Pengenalan Eksklusif (Jakarta: Kencana, 2010), 90.

${ }^{18}$ Muhammad, Ekonomi Mikro, 140.

19 Ibid.

${ }^{20}$ Ibid.
} 


\section{Teori Penawaran Islami}

Ibnu Khaldun menekankan bahwa kenaikan penawaran atau penurunan permintaaan menyebabkan kenaikan harga, demikian pula sebaliknya. Ia percaya bahwa akibat dari rendahmya harga akan merugikan perajin dan pedagang sehingga mereka akan keluar dari pasar, sedangkan akibat dari tingginya harga akan menyusahkan konsumen, terutama kaum miskin yang menjadi mayoritas dalam sebuah populasi. Karena itu, Ibnu Khaldun berpendapat bahwa harga rendah untuk kebutuhan pokok harus diusahakan tanpa merugikan produsen. Allah telah mempersiapkan bumi ini untuk kepentingan manusia sebagaimana telah tercantum dalam al-Quran:

$$
\begin{aligned}
& \text { الله الذي خلق السماوات والأرض وأنزل من السماء ماء فأخرج به من الثمرات رزقا لكم وسخر لكم الفلك } \\
& \text { *تجري في البحر بأمره وسخر لكم الأهمار * وسخر لكم الشمس والقمر دائبين وسخر لكم الليل والنهار } \\
& \text { وآتاكم من كل ما سألتموه وإن تعدوا نعمت الله لا تحصوها إن الإنسان لظلوم كفار } 21
\end{aligned}
$$

"Allah-lah yang telah menciptakan langit dan bumi dan menurunkan air hujan dari langit, kemudian Dia mengeluarkan dengan air hujan itu berbagai buah-buahan menjadi rezki untukmu; dan Dia telah menundukkan bahtera bagimu supaya bahtera itu berlayar di lautan dengan kehendak-Nya, dan Dia telah menundukkan (pula) bagimu sungaisungai (32). Dan Dia telah menundukkan (pula) bagimu matahari dan bulan yang terus menerus beredar (dalam orbitnya); dan Dia telah menundukkan bagimu malam dan siang (33). Dan Dia telah memberikan kepadamu (keperluanmu) dan segala apa yang kamu mohonkan kepadanya. dan jika kamu menghitung nikmat Allah, tidaklah dapat kamu menghinggakannya. Sesungguhnya manusia itu, sangat zalim dan sangat mengingkari (nikmat Allah) (34).”

$$
\begin{aligned}
& \text { ألم تروا أن الله سخر لكم ما في السماوات وما في الأرض وأسبغ عليكم نعمه ظاهرة وباطنة ومن الناس من يجادل } \\
& \text { في الله بغير علم ولا هدى ولا كتاب منير } 22
\end{aligned}
$$

"Tidakkah kamu perhatikan sesungguhnya Allah telah menundukkan untuk (kepentingan) mu apa yang di langit dan apa yang di bumi dan menyempurnakan untukmu nikmat-Nya lahir dan batin, dan di antara manusia ada yang membantah tentang (keesaan) Allah tanpa ilmu pengetahuan atau petunjuk dan tanpa kitab yang memberi penerangan."

$$
\text { وسخر لكم ما في السماوات وما في الأرض جميعا منه إن في ذلك لآيات لقوم يتفكرون23 }
$$

"Dan Dia telah menundukkan untukmu apa yang di langit dan apa yang di bumi semuanya, (sebagai rahmat) daripada-Nya. Sesungguhnya pada yang demikian itu

\footnotetext{
${ }^{21}$ al-Quran, 14: 32-34.

${ }^{22}$ Ibid., 31: 20.

${ }^{23}$ Ibid., 45: 13.
} 
benar-benar terdapat tanda-tanda (kekuasaan Allah) bagi kaum yang berfikir."

Berdasarkan penjelasan ayat al-Quran di atas dapat diketahui bahwa dalam memanfaatkan alam yang telah disediakan Allah bagi keperluan manusia. Larangan yang harus dipatuhi adalah tidak boleh membuat kerusakan di muka bumi. Meskipun definisi kerusakan tersebut sangat luas, akan tetapi dalam kaitannya dengan produksi larangan tersebut memberi arahan nilai dan panduan moral. Dalam ekonomi Islam ada empat hal yang perlu diperhatikan dalam menjalankan aktivitas ekonomi, yaitu ${ }^{24}$ larangan melakukan mafsadah, larangan melakukan gharär, larangan melakukan maysir dan larangan melakukan riba.

Dalam konsep Islam, mencegah mafsadah (kerusakan) lebih diutamakan daripada memperbaiki dampak buruk tersebut timbul sebagai ekses dari suatu produksi yang bermanfaat. ${ }^{25}$ Produksi islami bukan hanya dilarang mengakibatkan kerusakan dalam memanfaatkan alam dan lingkungan. Aturan etika dan moral yang membatasi kegiatan produksi tersebut tentu saja berpengaruh terhadap fungsi penawaran barang dan jasa. Sebagai contoh, apabila suatu proses produksi menghasilkan polusi, maka biaya lingkungan dan sosial tersebut harus dihitung dalam ongkos produksi sehingga ongkos meningkat dan penawaran akan berkurang. Dampaknya kurva penawaran akan bergeser ke kiri. ${ }^{26}$

\section{Faktor-Faktor yang Mempengaruhi Tingkat Penawaran}

Sebagai suatu mekanisme ekonomi, penawaran terjadi karena adanya beberapa faktor yang mempengaruhi. Faktor-faktor yang mempengaruhi produsen dalam menawarkan produknya adalah ${ }^{27}$ harga barang itu sendiri; harga barang-barang lain; ongkos dan biaya produksi; tujuan dari produksi perusahaan; dan teknologi yang digunakan.

Adapun faktor-faktor yang menentukan penawaran suatu barang menurut Nasution adalah: ${ }^{28}$

1. Biaya dan teknologi

Biaya adalah biaya yang dikeluarkan untuk memproduksi barang atau jasa yang meliputi biaya langsung dan biaya tidak langsung.

Teknologi adalah peningkatan teknologi yang diterapkan untuk menurunkan biaya produksi. Contohnya adalah otomatisasi produksi, penggunaan robot dan komputer, pemakaian perangkat lunak komputer baru dan sebagainya. Jika diterapkan teknologi baru yang mengakibatkan biaya produksi setiap unit barang menjadi lebih rendah, maka penerapan teknologi tersebut akan meningkatkan penawaran. Demikian pula bila diterapkan sistem manajemen yang mampu mempertinggi efisiensi produksi, maka penawaran akan meningkat atau kurva penawaran akan bergeser ke kanan. Artinya, dengan tingkat harga tertentu yang berlaku di pasar, akan lebih banyak jumlah barang yang ditawarkan karena biaya yang lebih rendah dalam memproduksinya.

\footnotetext{
${ }^{24}$ Muhammad, Ekonomi Mikro, 150.

25 Ibid.

${ }^{26}$ Mustofa Edwin Nasution, Ekonomi Islam, 95.

${ }^{27}$ Muhammad, Ekonomi Mikro, 140.

${ }^{28}$ Mustofa Edwin Nasution, Ekonomi Islam, 92.
} 
2. Jumlah penjual

Semakin banyak jumlah penjual yang mampu menjual pada tingkat harga tertentu maka semakin tinggi penawaran.

3. Dugaan tentang masa depan

Aspek dugaan atau ekspektasi terhadap masa depan mencakup dugaan mengenai perubahan harga dari barang tersebut. Misalnya, jika penjual menduga bahwa harga barangnya akan meningkat di masa yang akan datang, maka ia akan mengurangi penawarannya pada saat ini. Akibatnya penawaran berkurang. Hal ini dilarang oleh Nabi Muhammad, karena perilaku seperti ini mengakibatkan harga di pasar melonjak.

4. Kondisi alam

Kondisi alam seperti terjadinya bencana banjir, gempa bumi dan sebagainya bisa mengakibatkan penawaran barang-barang tertentu berkurang.

\section{Keseimbangan Permintaan dan Penawaran Dalam Islam}

Harga suatu barang dan jumlah barang yang diperjualbelikan ditentukan oleh permintaan dan penawaran barang tersebut. Oleh karena itu, untuk menganalisa mekanisme penentuan harga dan jumlah barang yang diperjualbelikan, secara serentak perlulah dianalisa permintaan dan penawaran terhadap suatu barang tertentu. ${ }^{29}$

Keadaan di suatu pasar dikatakan dalam keseimbangan atau ekuilibrium apabila jumlah yang ditawarkan para penjual pada suatu harga tertentu adalah sama dengan jumlah yang diminta para pembeli pada harga tersebut. Dengan demikian harga suatu barang dan jumlah barang yang diperjualbelikan dapat ditentukan dengan melihat keadaan keseimbangan dengan melihat keseimbangan dalam suatu pasar. ${ }^{30}$

Langkah selanjutnya ialah meletakkan kurva penawaran dan permintaan secara bersama-sama. ${ }^{31}$

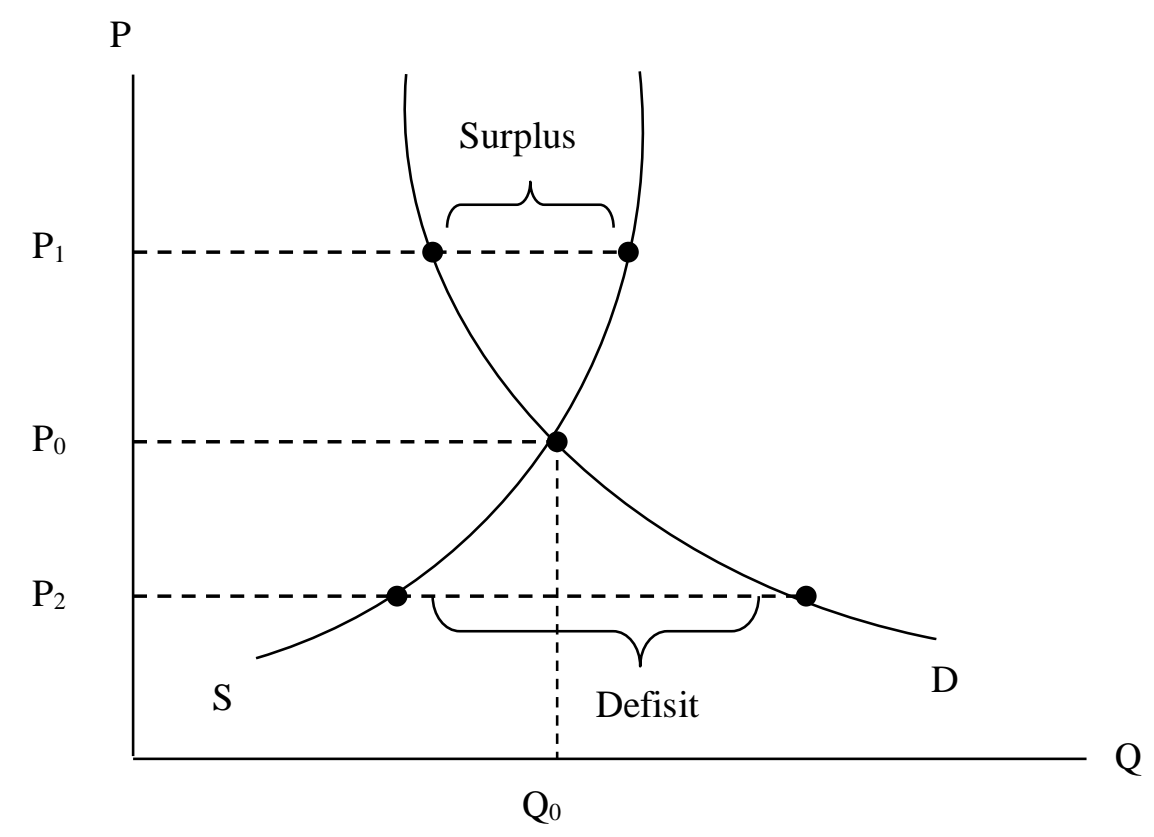

\footnotetext{
${ }^{29}$ Sadono Sukirno, Mikro Ekonomi: Teori Pengantar, 90.

${ }^{30}$ Ibid.

${ }^{31}$ Nur Rianto Al Arif dan Euis Amalia, Teori Mikroekonomi, 52.
} 
Suatu pasar akan mengalami keseimbangan jika jumlah barang yang ditawarkan sama dengan jumlah barang yang diminta dan tidak ada kekuatan internal yang menyebabkan perubahan. Sekali dicapai keseimbangan ini cenderung untuk tidak berubah. Secara geometris, keseimbangan terjadi pada saat kurva penawaran berpotongan dengan kurva permintaan pasarnya. ${ }^{32}$

Kedua kurva saling berpotongan pada jumlah dan harga keseimbangan (equilibrium price). Pada harga ini $\mathrm{P}_{0}$ dalam gambar di atas, jumlah penawaran dan permintaan ialah sama dengan $\mathrm{Q}_{0}$. Pada titik ini tidak ada kekurangan atau kelebihan penawaran, juga tidak ada tekanan terhadap harga untuk berubah lagi. Di mana masing-masing tingkat harga mampu bergerak sesuai dengan perubahan tingkat permintaan dan tingkat penawaran yang terjadi di pasar. $^{33}$

Misalkan pada awalnya harga berada di atas tingkat keseimbangan pasar, katakan $\mathrm{P}_{1}$ pada gambar di atas, maka produsen akan berusaha memproduksi dan menjual lebih daripada yang bersedia dibeli konsumen. Karenanya akan terjadi surplus, yaitu jumlah penawaran lebih banyak dibandingkan jumlah permintaan. Untuk menjual surplus ini, produsen akan mulai menurunkan harga sampai dengan harga keseimbangan tercapai. ${ }^{34}$

Hal yang sebaliknya akan terjadi jika harga mula-mula ada di bawah $\mathrm{P}_{0}$, katakanlah $\mathrm{P}_{2}$. Kekurangan akan terjadi karena jumlah permintaan melebihi jumlah barang yang ditawarkan oleh produsen. Ini akan mengakibatkan tekanan ke atas terhadap harga karena sesama konsumen akan saling bersaing satu sama lain untuk mendapatkan penawaran yang ada, dan produsen merespon dengan menaikkan harga dan menambah barang, sehingga akhirnya akan mencapai harga keseimbangan $\mathrm{P}_{0}{ }^{35}$

\section{Kesimpulan}

Dari hasil penelitian di atas, maka dapat disimpulkan bahwa pertama, dalam kurva permintaan dan penawaran Islam terdapat batasan-batasan yang harus dilakukan sebagai seorang muslim yang digunakan sebagai dasar untuk berperilaku ekonomi. Batasan-batasan tersebut adalah larangan untuk melakukan mafsadah, gharär, maysir, dan riba. Konsep permintaan dan penawaran dalam Islam bertujuan mendapatkan kesejahteraan atau kemenangan akhirat (falah) sebagai turunan dari keyakinan bahwa ada kehidupan yang abadi setelah kematian, yaitu kehidupan akhirat sehingga anggaran yang ada harus disisihkan sebagai bekal untuk kehidupan akhirat, seperti sedekah dan zakat. Ini berarti terdapat perbedaan yang signifikan antara teori permintaan konvensional dengan teori permintaan Islam. Dalam ilmu ekonomi konvensional para konsumen dan produsen memiliki motivasi yang didominasi oleh nilai-nilai kepuasan, tetapi dalam ekonomi Islam menekankan terhadap tingkat kebutuhan semata.

Kedua, dalam mekanisme keseimbangan harga dalam Islam ini ditentukan oleh keseimbangan antara permintaan dan penawaran. Ini berarti keseimbangan harga yang ada di pasar terbentuk dengan alamiah bukan karena ada campur tangan dari pemilik modal

\footnotetext{
${ }^{32}$ Joesron Tati Suhartati, Teori Ekonomi Mikro (Jogjakarta: Graha Ilmu, 2012), 83.

${ }^{33}$ Nur Rianto Al Arif dan Euis Amalia, Teori Mikroekonomi, 51.

${ }^{34}$ Ibid.

${ }^{35}$ Ibid.
} 
(kapitalis) yang bisa mendistorsi pasar. Ini menunjukkan bahwa ketentuan harga itu diserahkan kepada mekanisme pasar yang alamiah impersonal, karena Allah lah yang menentukannya.

\section{Daftar Rujukan}

Al Arif, Nur Rianto dan Euis Amalia. Teori Mikroekonomi: Suatu Perbandingan Ekonomi Islam dan Ekonomi Konvensional. Jakarta: Kencana, 2010.

Hafidh, Abdul. "Konsep Penawaran dalam Perspektif Islam”. JEBIS. Vol. 1, No. 2, JuliDesember 2015.

Karim, Adiwarman A. Ekonomi Mikro Islam. Jakarta: Rajawali Press, 2012.

Muhammad. Ekonomi Mikro dalam Perspektif Islam. Jogjakarta: BPFE, 2004.

Nasution, Mustofa Edwin. Ekonomi Islam: Pengenalan Eksklusif. Jakarta: Kencana, 2010.

Nawawi, Ismail. Ekonomi Mikro dalam Perspektif Islam. Jakarta: CV. Dwiputra Pustaka Jaya, 2010.

Nuryadin, H.M Birusman. "Harga dalam Perspektif Islam”. Jurnal Ekonomi. Vol. IV, No. 1, Juni 2007.

Suhartati, Joesron. Teori Ekonomi Mikro. Jogjakarta: Graha Ilmu, 2012.

Sukirno, Sadono. Mikro Ekonomi: Teori Pengantar. Jakarta: PT. Raja Grafindo Persada, 2010. 